\title{
The Effects of Systemic Infusion of Bradykinin on Experimental Peritoneal Fibrosis
}

\author{
${ }^{1}$ Necdet Fatih Yaşar, ${ }^{2}$ Onur Uysal, ${ }^{1}$ Mehmet Burak Öztop, \\ ${ }^{3}$ Canan Baydemir, ${ }^{1}$ Enver İhtiyar \\ ${ }^{1}$ Department of General Surgery, School of Medicine, Eskişehir Osmangazi University, Eskişehir, \\ ${ }^{2}$ Vocational School of Health Services, Eskişehir Osmangazi University, Eskisehir, Turkey. \\ ${ }^{3}$ Department of Biostatistics, School of Medicine, Kocaeli University, Kocaeli, Turkey. \\ e-posta: ouysal1971@gmail.com
}

\begin{abstract}
Background. Bradykinin (BK) is a proinflammatory peptide that is involved in the inflammation and vascular regulation. Recent studies have indicated that stimulation of BK-B2 receptors may attenuate fibrosis in renal and liver injuries and it is also expressed on neutrophils.Objectives. The aim of this study is to investigate the expression of bradykinin-B2 receptors and to explore the effects of systemic infusion of bradykinin (BK) using histochemical and immunohistochemical methods in a rodent model of chlorhexidine gluconate-induced peritoneal fibrosis.Materials and Methods. In this experimental study, twenty-four male SpragueDawley rats $(n=24)$ were divided into three groups; Control, Chlorhexidine Gluconate (CG) and Chlorhexidine Gluconate+Bradykinin treatment $(\mathrm{CG}+\mathrm{BK})$. All animals were euthanized at day 21 and peritoneal tissue samples were taken under anesthesia induced by $50 \mathrm{mg} / \mathrm{kg}$ s.c. sodium pentothal. Histological assessments were then performed using hematoxylin and eosin, Periodic Acid-Schiff staining; and antibodies against TGF- $\beta 1$, MMP-2, PAI-1 and bradykinin-B2 (BK-B2) receptors.Results. Thickness of submesothelial layer, neovascularization, polimorphonuclear granulocytes and fibrosis increased in the CG+BK treatment group. While expression of TGF- $\beta 1$, MMP-2 and PAI-1 was not significantly different than that of the CG group. Staining of BK-B2 receptors was up-regulated in the submesothelial compact zone of the $\mathrm{CG}+\mathrm{BK}$ treatment group.Conclusions. The results of our study showed that the stimulation of BK-B2 receptors by systemic BK perfusion did not have any antifibrotic effects in the encapsulating peritoneal sclerosis rat models, and actually, it may even promote fibrosis by aggravating inflammation.
\end{abstract}

KEY WORDS: peritoneal fibrosis, TGF- $\beta 1$, MMP-2, PAI-1, BK-B2 receptors

ÖZET: Bu çalışmanın amacı klorheksidin glukonat ile oluşturulan rodent peritoneal fibrozis modelinde bradikinin-B2 reseptör ekspresyonunun araştırılması ve sistemik bradikinin infüzyonunun etkisinin histokimyasal ve immünhistokimyasal metodlarla ortaya konulmasıdır. $\mathrm{Bu}$ deneysel çalışmada, 24 Sprague-Dawley cinsi rat 3 gruba ayrıldı; Kontrol, Klorheksidin Glukonat $(\mathrm{KG})$ ve Klorheksidin Glukonat + Bradikinin tedavisi $(\mathrm{KG}+\mathrm{BK})$. Kontrol grubunda ratlara günlük serum fizyolojik (10 mL/kg i.p.) verildi. $\mathrm{KG}$ ve $\mathrm{KG}+\mathrm{BK}$ gruplarında peritoneal fibrozis, 3 hafta boyunca günlük, $10 \mathrm{~mL} / \mathrm{kg}$ dozunda serum fizyolojik içinde çözülen $\% 0.1 \mathrm{KG}$ ve $\% 15$ etanol i.p. enjeksiyonları ile oluşturuldu. KG grubunda ratlara serum fizyolojik infüzyonu $(0.25 \mu \mathrm{L} / \mathrm{h})$ verilirken, $\mathrm{KG}+\mathrm{BK}$ tedavisi grubunda ratlara 3 hafta boyunca ozmotik mini pompalar vasıtasıly serum fizyolojik içinde çözülmüş bradikinin $(100 \mathrm{ng} / \mathrm{kg} / \mathrm{min})$ subkutan verildi. Tüm hayvanlar i.p. enjeksiyonlarının 21. Gününde, önceki gece yiyecek ve su kesildikten sonra $50 \mathrm{mg} / \mathrm{kg}$ s.c. sodyum pentotal anestezisi altında sakrifiye edildi ve peritoneal örnekler alındı. Histolojik değerlendirme hematoksilen- eozin ve Periodik Acid-Schiff boyaları kullanılarak; immünhistolojik değerlendirme TGF- $\beta 1$, MMP-2, PAI-1 ve bradikinin-B2 (BK-B2) reseptörleri antikorları kullanılarak 1ş1k mikroskobisi altında yapıldı. Submezotelyal tabakanın kalınlığı, neovaskülarizasyon, polimorfonükleer granülositler ve fibrozis $\mathrm{KG}+\mathrm{BK}$ tedavisi grubunda artmışken, TGF- $\beta 1$, MMP-2 ve PAI-1 ekspresyonu KG grubuna kıyasla anlamlı bir farklılık göstermedi. BK-B2 reseptör boyaması $\mathrm{KG}+\mathrm{BK}$ tedavi grubunda submezotelyal kompakt zonda artmıştı. Çalışmamızın sonuçları sistemik BK perfüzyonu ile stimüle edilen BK-B2 reseptörlerinin enkapsüle peritoneal sklerozis rat modelinde herhangi bir antifibrotik etkilerinin olmadığını ve aslında inflamasyonu daha da artırarak fibrozisi daha da artırabileceğini göstermektedir.

ANAHTAR KELIMELER: bradikinin, klorheksidin glukonat, peritoneal fibrozis, TGF- $\beta 1$, MMP-2, PAI-1, BK-B2 reseptörleri, rat 


\section{Introduction}

Peritoneal injury, due to surgery, infection or irritation, leads to encapsulating peritoneal sclerosis (EPS). Symptoms of EPS are usually progressive and strongly refractory to the treatment. However, the precise mechanism leading to EPS still remains unknown. The most prominent features of EPS are complete mesothelial denudation and the progressive fibrosis in the parietal and visceral peritoneum [1-6]. Peritoneal fibrosis occurs in peritoneal dialysis patients in response to a variety of injuries, including bio-incompatible dialysate solutions, peritonitis, uremia, and chronic inflammation [7].

Normal peritoneal membrane is composed of a monolayer of mesothelial cells of mesenchymal origin, resting on a continuous basement membrane supported by the submesothelium. The mesothelial cells are a homogeneous population with either a flattened, stretched and squamous appearance, or cuboidal. Cuboidal mesothelial cells are also observed within an injured or stimulated mesothelium. Submesothelial compact zone (SCZ) is a fibrous tissue layer which is located between mesothelial layer and subserous fatty tissue and contains extracellular matrix (ECM) comprising of various collagens, glycoproteins, glycolsaminoglycans and proteoglycans $[3,4,8]$.

Injury of the peritoneum causes desquamation of injured mesothelial cells, leaving a denuded area and causing an inflammatory reaction, characterized by cellular infiltration, formation of serosanguinous exudate and a growth response by the mesothelial cells. Resident cells and the damaged mesothelial cells as well as the inflammatory cells invading the injured area produce cellular mediators, leading to increased vascular permeability andmigration of polymorphonuclear granulocytes (PMN's), monocytes and leucocytes to the site of inflammation. PMN's are the first cell type appearing at

the damaged area and they persist at the injured site for 1-2 days. They are followed by monocytes, which differentiate into macrophages and then adhere to the wound surface $[4,8,9]$. The switch in the phenotype of leukocytes from neutrophils to macrophages is important for the development of inflammation and tissue fibrosis [5].

Although pathogenesis of EPS is partly understood, increase in the profibrotic cytokines and inflammatory cell activities, neovascularization, and epithelial-tomesenchymal differentiation are the main features of the pathophysiology [10]. Mesothelial cells can cause peritoneal fibrosis by secreting ECM macromolecules which are comprised of collagen, fibronectin, laminin, proteoglycans, and cytokines, including transforming growth factor- $\beta$ (TGF- $\beta$ ) and interleukin-1 (IL-1). TGF- $\beta$, IL-1 and hepatocyte growth factor increase the release of matrix metalloproteinases (MMPs) from mesothelial cells. MMPs may play an important role in the development of peritoneal fibrosis via angiogenesis and cell infiltration. Moreover, studies support the view that the family of MMPs, especially MMP-2, is released mainly from fibroblasts, epithelial cells and macrophages and they play an important role in peritoneal fibrosis in animal models and patients with EPS [7, 10-12].

Plasminogen activator-1 (PAI-1) is produced by endothelial cells, mesothelial cells, monocytes, macrophages and fibroblasts. The balance between plasminogen activators and plasminogen inhibitors is crucial in determining normal healing or adhesion formation. Therefore, PAI-1 is considered as an important factor in the development of adhesions, and high PAI-1 concentrations are determined in 
adhesions and peritoneal tissue of patients with extensive adhesions $[1,5,7,8]$.

Bradykinin (BK) is a proinflammatory peptide that is involved in the inflammation and vascular regulation, including processes such as angioedema, tissue permeability, vascular dilation, and the contraction of smooth muscles [13, 14]. BK exerts its effects via the specific receptors, B1 and B2 [15, 16]. Recent studies have indicated that stimulation of BK-B2 receptors may attenuate fibrosis in renal and liver injuries [16-19] and it is also expressed on neutrophils [20].

An experimental rat and mice model of EPS, which is induced i.p. administration of chlorhexidine gluconate (CG), has been described. In this model, the adhesions of the peritoneum were very similar to those seen in patients with EPS, and thickening of the SCZ, increase in the number of vessels and fibroblasts and increased collagen deposition as well as peritoneal fibrosis were observed [5].

In the light of these experimental evidences, the current study investigates the expression of BK-B2 receptors and explores the effects of systemic infusion of $\mathrm{BK}$ in a rodent model of CG-induced peritoneal fibrosis

\section{Materials and Methods}

\section{Animals}

Twenty-four male Sprague-Dawley rats $(\mathrm{n}=24)$ weighing 250-300 g were supplied from the Eskisehir Osmangazi University Experimental Research Center. Rats were housed in polycarbonate cages in a temperature $\left(21 \pm 1^{\circ} \mathrm{C}\right)$ and humidity $(45$ $55 \%)$ controlled room which was maintained on a 12/12 reversed light cycle. They were fed with a standard rat chow (Oguzlar Yem, Eskisehir, Turkey) and allowed to drink ad libitum. This study was approved by the Eskisehir
Osmangazi University Institutional Animal Care and Use Committee.

\section{Experimental Procedure}

The animals were divided into three groups. In the Control group $(n=8)$, rats received only saline i.p. $(10 \mathrm{~mL} / \mathrm{kg})$ daily. In Chlorhexidine Gluconate (CG) group $(\mathrm{n}=8) \quad$ and Chlorhexidine Gluconate+Bradykinin $\quad(\mathrm{CG}+\mathrm{BK})$ treatment group $(n=8)$, peritoneal fibrosis was induced by daily i.p. injection of $0.1 \% \mathrm{CG}$ in $15 \%$ ethanol dissolved in saline at a volume of $10 \mathrm{~mL} / \mathrm{kg}$ body weight for 3 weeks as described previously by Mishima et al [21]. To avoid direct damage to the peritoneum caused by repeated injections, injections were made at the lower part of the peritoneum, while the upper portion of the peritoneum was used for the following histologic examinations. In CG group, the rats were infused with saline $(0.25 \mu \mathrm{L} / \mathrm{h})$ whereas in $\mathrm{CG}+\mathrm{BK}$ treatment group, the rats were treated with bradykinin at 100 $\mathrm{ng} / \mathrm{kg} / \mathrm{min}$ dissolved in saline through s.c. osmotic minipumps (Alzet Corp, Cupertino, CA, USA) during the 3 weeks of $\mathrm{CG}$ treatment. At 21 days of the first i.p. injections, animals were euthanized after an overnight fast and tissue samples were taken from all of the rats under 50 $\mathrm{mg} / \mathrm{kg}$ s.c. sodium pentothal anesthesia.

\section{Histological Observations}

All of the specimens were carefully aroused and fixed in neutral buffered formalin for histological analyses. After the fixation, the tissues were embedded in paraffin, serial sections $(4 \mu \mathrm{m})$ being prepared for each of the paraffin blocks. On the average, 50 sections were collected per rat. Sections were stained for histological analyses with hematoxylin and eosin (H\&E) and Periodic Acid-Schiff (PAS) staining methods.

After deparaffinisation, hydrogenous peroxidase was quenched with distilled 
water. The sections were permeabilized with phosphate buffer solution ( $\mathrm{pH}$ 7.4) and stained with antibodies against TGF$\beta 1$, MMP-2, PAI- 1 and BK-B2 receptors (Santa Cruz, Biotechnology, CA, USA). Digital images were obtained by an Olympus BX-61 (Olympus America Inc. NY, USA) microscope with a DP70 digital camera. The histological evaluation was semi-quantitatively scored by two independent observers who undertook the evaluation using an ocular micrometer by light microscopy.

The severity of histological changes in the peritoneal membrane was scored viz. (0), no changes; (1), mild; (2), moderate and (3) severe. Mesothelial cells were classified as "normal" (flat cells) or "reactive" (cubic transformation of flat cells). The examination of the changes in the mesothelial cells consisted of the evaluation of the following: increase of the number of cells and reactive cubicshaped cells. On the other hand, the examination of changes in the SCZ consisted of the evaluation of the following: peritoneal thickening, neovascularisation, intersititial edema, fibrosis, PMN's and monocyte/macrophage infiltrations $[2,6$, 12, 22-25].

The severity of histological changes in the peritoneal basal membrane thickness, fibrosis and the presence of fibrin was scored; (0), no changes; (1), mild; (2), moderate and (3) severe [26].

TGF- $\beta 1, \quad$ MMP-2, PAI-1 and BK-B2 respectively, as the tissue by immunohistochemical stains were examined by light microscopy. The evaluation of staining intensity, respectively negative (0), weak (1), mild (2), severe (3) were scored. When making an assessment flat and cubic mesothelial cells, fibroblasts submesothelial compact zone, the surface of endothelial cells and monocytes/macrophages staining intensities were compared [10, 12, 27].

\section{Statistical Analysis}

Statistical analysis was performed using SigmaStat for Windows Version 3.5 (Systat Software Inc. Germany). Statistical significance was defined as $\mathrm{p}<0.05$. The Kolmogorov-Smirnov test was applied to examine normal distribution. For the comparison between groups Kruskal Wallis Analysis of Variance test were used. Data were presented as median (25\%-75\% percentiles).

\section{Results}

\section{Histological Observations}

The results of the histopathological parameters in all the groups are summarized in the Table 1 . The number of the squamous mesothelial cells increased significantly in $\mathrm{CG}$ group ( $p<0.05)$, whereas the number of the reactive cubic-shaped mesothelial cells was higher in $\mathrm{CG}+\mathrm{BK}$ treatment group than in $C G$ group $(p<0.05)$. On the other hand, thickening of SCZ, neovascularization, interstitial edema, fibrosis, PMN's and monocyte/macrophage infiltration was increased significantly both in CG and $\mathrm{CG}+\mathrm{BK}$ treatment groups compared to control group $(p<0.05)$. Even if these histological alterations were more severe in $\mathrm{CG}+\mathrm{BK}$ treatment group than in CG group, the difference was statistically not significant (Table 1) (Fig. 1).

PAS staining method revealed that thickness of basal membrane was increased significantly in $\mathrm{CG}$ and $\mathrm{CG}+\mathrm{BK}$ treatment groups compared to control group significantly $(\mathrm{p}<0.05)$ while there was no difference between the treatment groups in concordance with the H\&E staining method. There was no significant difference in the presence of fibrin between the groups (Table 2) (Fig. 2). 
Table 1

Histological changes in the peritoneal membrane (H\&E)

\begin{tabular}{|c|c|c|c|c|c|}
\hline \multirow[t]{2}{*}{ GROUPS } & \multicolumn{4}{|c|}{ Median (25\%-75\% Percentiles) } & \multirow[t]{2}{*}{$\mathbf{H}(\mathbf{P})$} \\
\hline & & Control Group & CG Group & CG+BK Trea & \\
\hline \multirow{4}{*}{$\begin{array}{l}\text { Mesothelial } \\
\text { Cells Changes }\end{array}$} & $\begin{array}{l}\text { Increase of the flat } \\
\text { cells number }\end{array}$ & $0.00(0.00-0.00)$ & $1.50(0.50-2.50)$ & $0.00(0.00-0.00)$ & $14.964(<0.001)^{\mathrm{A}, \mathrm{C}}$ \\
\hline & $\begin{array}{l}\text { Increase of the } \\
\text { reactive cubic-shaped } \\
\text { cells number }\end{array}$ & $0.00(0.00-0.00)$ & $0.50(0.00-2.50)$ & $2.00(2.00-3.00)$ & $13.668(<0.001)^{\mathrm{B}}$ \\
\hline & Peritoneal thickening & $0.00(0.00-0.00)$ & $2.00(2.00-2.50)$ & $3.00(2.50-3.00)$ & $18.688(<0.001)^{\mathrm{A}, \mathrm{B}}$ \\
\hline & Neovascularisation & $0.00(0.00-0.00)$ & $2.00(2.00-2.00)$ & $3.00(2.00-3.00)$ & $18.850(<0.001)^{\mathrm{A}, \mathrm{B}}$ \\
\hline $\begin{array}{l}\text { Submesothelial } \\
\text { Compact }\end{array}$ & Interstitial edema & $0.00(0.00-0.00)$ & $2.00(2.00-2.50)$ & $3.00(2.00-3.00)$ & $18.129(<0.001)^{\mathrm{A}, \mathrm{B}}$ \\
\hline Zone & Fibrosis & $0.00(0.00-0.00)$ & $2.00(2.00-2.50)$ & $3.00(2.50-3.00)$ & $18.618(<0.001)^{\mathrm{A}, \mathrm{B}}$ \\
\hline \multirow[t]{2}{*}{ Changes } & PMN's infiltration & $0.00(0.00-0.00)$ & $1.00(1.00-1.00)$ & $2.00(1.50-3.00)$ & $14.524(<0.001)^{\mathrm{A}, \mathrm{B}}$ \\
\hline & $\begin{array}{l}\text { Monocyte/macrophage } \\
\text { infiltration }\end{array}$ & $0.00(0.00-0.00)$ & $2.00(1.50-2.50)$ & $2.50(2.00-3.00)$ & $17.095(<0.001)^{\mathrm{A}, \mathrm{B}}$ \\
\hline
\end{tabular}

(0), no changes; (1), mild; (2), moderate and (3) severe

A: $p<0.05$ for control group and CG group

B: $p<0.05$ for control group and $\mathrm{CG}+\mathrm{BK}$ treatment group

C: $\mathrm{p}<0.05$ for $\mathrm{CG}$ group and $\mathrm{CG}+\mathrm{BK}$ treatment group

$\mathrm{H}$ : Kruskal-Wallis variance analyses

Table 2

Histological changes in the peritoneal membrane (PAS)

\begin{tabular}{|c|c|c|c|c|}
\hline \multirow[t]{2}{*}{ GROUPS } & \multicolumn{3}{|c|}{ Median (25\%-75\% Percentiles) } & \multirow[t]{2}{*}{$\mathbf{H}(\mathbf{P})$} \\
\hline & Control Group & CG Group & CG+BK Treatm & \\
\hline $\begin{array}{l}\text { Basal } \\
\text { membrane } \\
\text { thickening }\end{array}$ & $0.00(0.00-0.00)$ & $3.00(2.50-3.00)$ & $3.00(3.00-3.00)$ & $20.491(<0,001)^{\mathrm{A}, \mathrm{B}}$ \\
\hline Fibrosis & $0.00(0.00-0.00)$ & $2.00(2.00-2.50)$ & $3.00(3.00-3.00)$ & $20.810(<0.001)^{\mathrm{A}, \mathrm{B}}$ \\
\hline $\begin{array}{l}\text { Presence of } \\
\text { fibrin }\end{array}$ & $0.00(0.00-0.00)$ & $0.50(0.00-1.00)$ & $0.00(0.00-0.00)$ & $6.295(>0.05)$ \\
\hline
\end{tabular}

(0), absent; (1), mild; (2), moderate and (3) severe

$\mathrm{H}$ : Kruskal-Wallis variance analyses

A: $p<0.05$ for control group and $C G$ group

B: $\mathrm{p}<0.05$ for control group and $\mathrm{CG}+\mathrm{BK}$ treatment group 
In all groups, flat and reactive cubic-shaped mesothelial cells did not reveal TGF- $\beta 1$ staining. Staining of fibroblasts and monocyte/macrophages in the SCZ for TGF- $\beta 1$ was significantly greater in $\mathrm{CG}$ and $\mathrm{CG}+\mathrm{BK}$ treatment groups than in control group $(\mathrm{p}<0.05)$. In fact, it was greatest in $\mathrm{CG}$ group but the difference between $\mathrm{CG}$ and $\mathrm{CG}+\mathrm{BK}$ treatment groups was insignificant. On the other hand, staining of the surface of the endothelial cells was greater only in $\mathrm{CG}$ group than in $\mathrm{CG}+\mathrm{BK}$ treatment group $(\mathrm{p}<0.05)$ (Table 3) (Fig. 3).

In all groups, flat and reactive cubicshaped mesothelial cells did not reveal MMP-2 staining. Fibroblasts in the SCZ were stained weakly in control group and even weaker in $\mathrm{CG}$ and $\mathrm{CG}+\mathrm{BK}$ treatment groups $(p<0.05)$. The expression of MMP2 on the surface of the endothelial cells in $\mathrm{CG}$ and $\mathrm{CG}+\mathrm{BK}$ treatment groups were greater than in control group $(\mathrm{p}<0.05)$. Monocyte/macrophages in control and CG groups did not reveal any expression of MMP-2 whereas weakly but significantly greater in $\mathrm{CG}+\mathrm{BK}$ treatment group $(\mathrm{p}<0.05)$ (Table 4) (Fig. 4).

Staining of the surface of the endothelial cells for PAI-1 was significantly greater in $\mathrm{CG}$ and $\mathrm{CG}+\mathrm{BK}$ treatment groups $(\mathrm{p}<0.05)$ than control group and there were no differences between the groups in other parameters (Table 5) (Fig. 5).

Table 3

TGF- $\beta 1$ immunohistochemical staining findings.

\begin{tabular}{lll}
\hline GROUPS & Median (25\%-75\% Percentiles) & H (P)
\end{tabular}

Control Group CG Group CG+BK Treatment Group

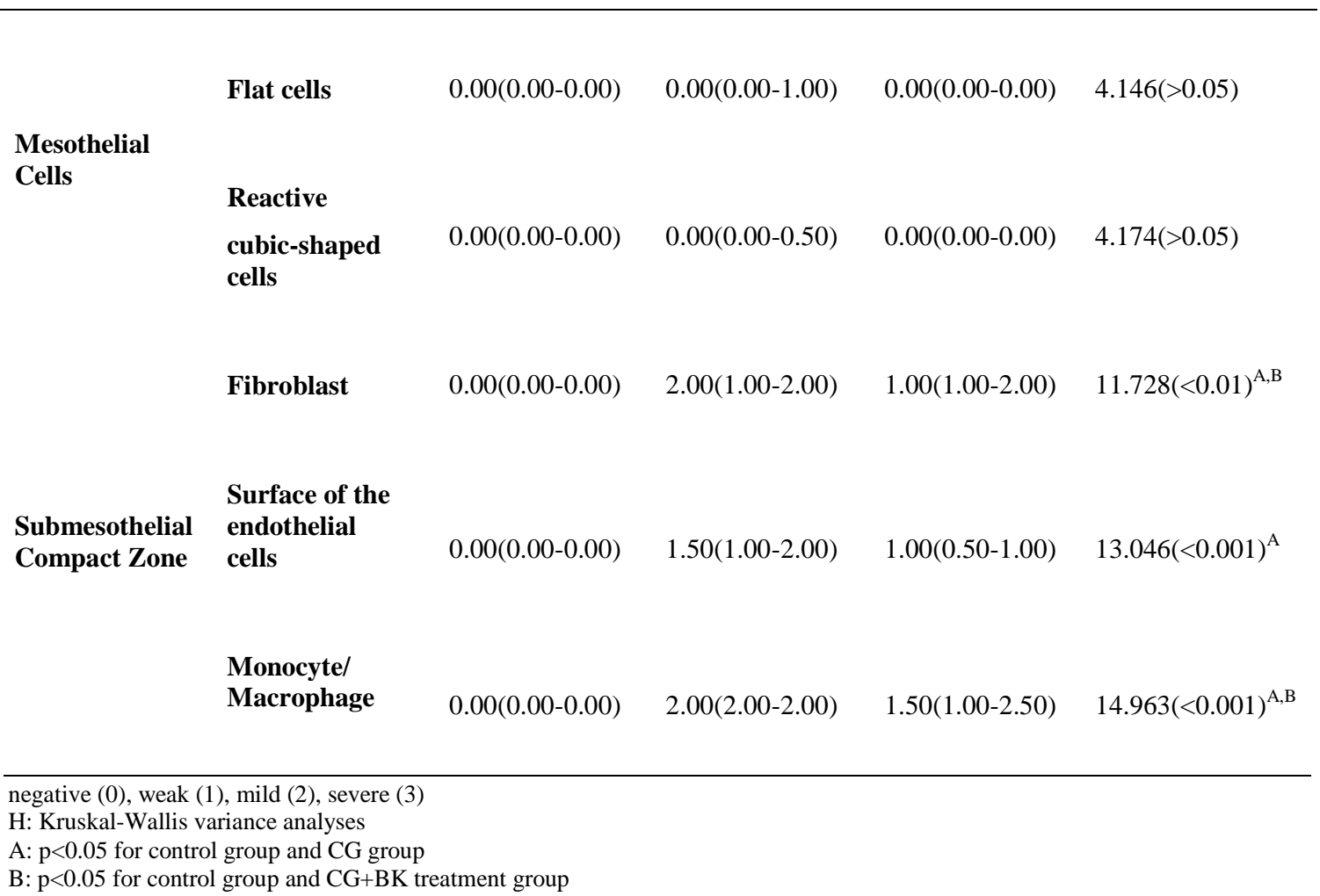


Table 4

MMP-2 immunohistochemical staining findings

\begin{tabular}{|c|c|c|c|c|c|}
\hline \multirow[t]{2}{*}{ GROUPS } & & \multicolumn{3}{|c|}{ Median (25\%-75\% Percentiles) } & \multirow[b]{2}{*}{ ent Group } \\
\hline & & Control Group & CG Group & CG+BK Treatn & \\
\hline \multirow[b]{2}{*}{$\begin{array}{l}\text { Mesothelial } \\
\text { Cells }\end{array}$} & Flat cells & $0.00(0.00-0.00)$ & $0.00(0.00-0.00)$ & $0.00(0.00-0.00)$ & $0.000(>0.05)$ \\
\hline & $\begin{array}{l}\text { Reactive } \\
\text { cubic-shaped } \\
\text { cells }\end{array}$ & $0.00(0.00-0.00)$ & $0.00(0.00-0.00)$ & $0.00(0.00-0.00)$ & $0.000(>0.05)$ \\
\hline \multirow{3}{*}{$\begin{array}{l}\text { Submesothelial } \\
\text { Compact Zone }\end{array}$} & Fibroblast & $1.00(1.00-1.00)$ & $0.00(0.00-0.00)$ & $0.00(0.00-1.50)$ & $9.266(<0.05)^{\mathrm{B}}$ \\
\hline & $\begin{array}{l}\text { Surface of the } \\
\text { endothelial } \\
\text { cells }\end{array}$ & $0.00(0.00-0.00)$ & $1.00(1.00-1.00)$ & $1.00(1.00-1.00)$ & $19.422(<0.001)^{\mathrm{A}, \mathrm{B}}$ \\
\hline & $\begin{array}{l}\text { Monocyte/ } \\
\text { Macrophage }\end{array}$ & $0.00(0.00-0.00)$ & $0.00(0.00-0.00)$ & $1.00(1.00-1.00)$ & $18.667(<0.001)^{\mathrm{B}, \mathrm{C}}$ \\
\hline $\begin{array}{l}\text { negative }(0) \text {, weak } \\
\text { H: Kruskal-Wallis } \\
\text { A: } p<0.05 \text { for contr } \\
\text { B: } p<0.05 \text { for contr } \\
\text { C: } p<0.05 \text { for CG g1 }\end{array}$ & $\begin{array}{l}\text { mild (2), severe ( } \\
\text { riance analyses } \\
\text { group and CG grou } \\
\text { group and CG+BK } \\
\text { up and CG+BK tre }\end{array}$ & $\begin{array}{l}\text { ment group } \\
\text { at group }\end{array}$ & & & \\
\hline
\end{tabular}

Table 5

PAI-1 immunohistochemical staining findings

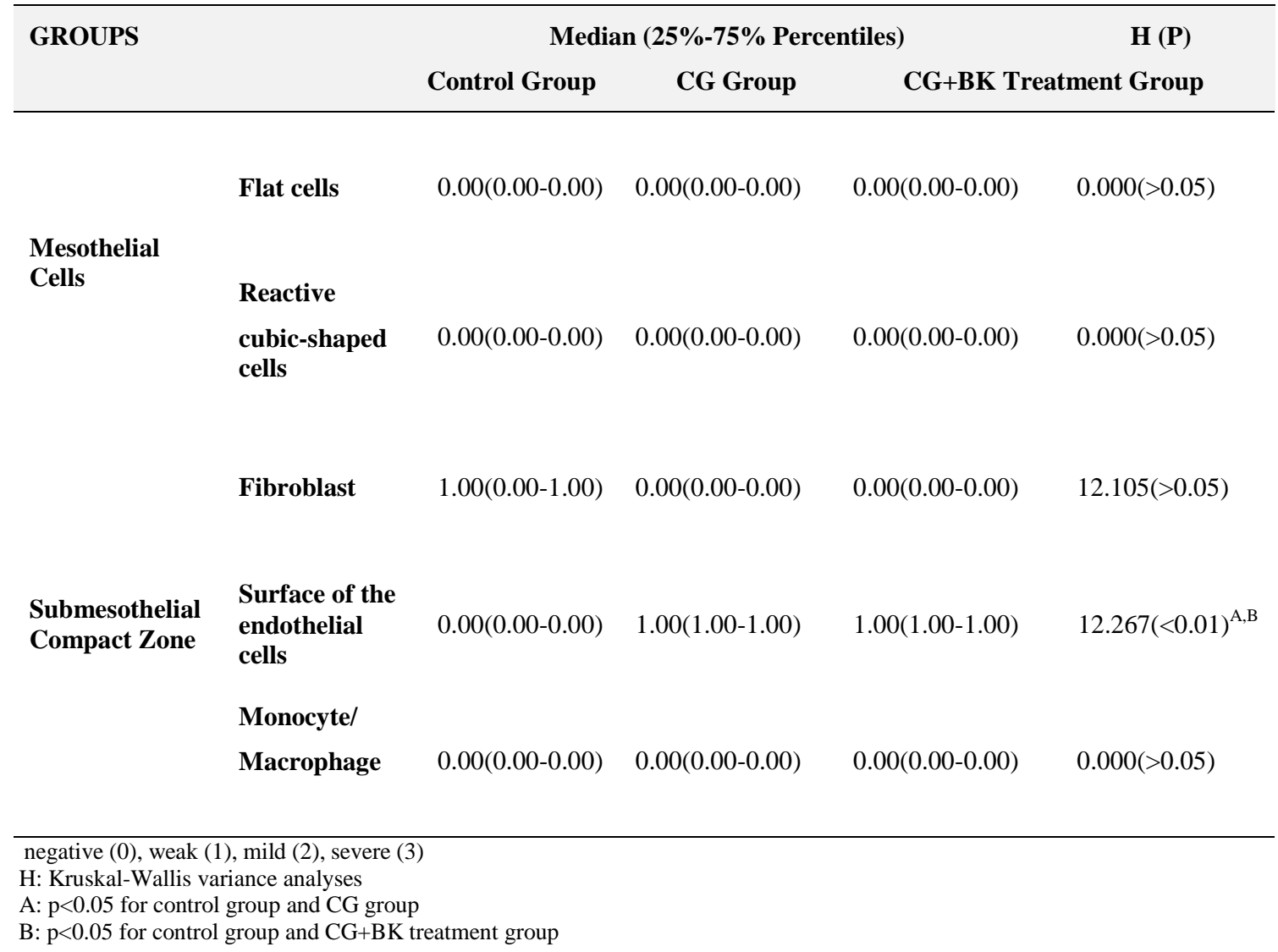


In control group, flat mesothelial cells had slight positive staining for BK-B2 receptors whereas in $\mathrm{CG}$ and $\mathrm{CG}+\mathrm{BK}$ treatment groups, no staining was observed ( $\mathrm{p}<0.05)$. Reactive cubic-shaped mesothelial cells were not stained in all groups. Even though staining of fibroblasts in $\mathrm{CG}+\mathrm{BK}$ treatment group was greater than in the other groups, the difference was not significant. Surface of the endothelial cells and monocyte/macrophages staining was significantly greater in $\mathrm{CG}+\mathrm{BK}$ treatment group than in control group $(\mathrm{p}<0.05)$, however the difference between the CG and $\mathrm{CG}+\mathrm{BK}$ treatment groups was not remarkable (Table 6) (Fig. 6).

Table 6.

BK-B2 immunohistochemical staining findings.

\begin{tabular}{|c|c|c|c|c|c|}
\hline \multirow[t]{2}{*}{ GROUPS } & & \multicolumn{3}{|c|}{ Median (25\%-75\% Percentiles) } & \multirow[t]{2}{*}{$\mathbf{H}(\mathbf{P})$} \\
\hline & & Control Group & CG Group & CG+BK Treatm & \\
\hline \multirow{4}{*}{$\begin{array}{l}\text { Mesothelial } \\
\text { Cells }\end{array}$} & Flat cells & $1.00(0.50-1.00)$ & $0.00(0.00-0.00)$ & $0.00(0.00-0.00)$ & $15.333(<0.001)^{\mathrm{A}, \mathrm{B}}$ \\
\hline & Reactive & & & & \\
\hline & $\begin{array}{l}\text { cubic-shaped } \\
\text { cells }\end{array}$ & $0.00(0.00-0.00)$ & $0.00(0.00-0.00)$ & $0.00(0.00-0.00)$ & $0.000(>0.05)$ \\
\hline & Fibroblast & $1.00(0.50-1.00)$ & $1.50(1.00-2.00)$ & $2.00(1.00-2.00)$ & $6.955(>0.05)$ \\
\hline \multirow{2}{*}{$\begin{array}{l}\text { Submesothelial } \\
\text { Compact Zone }\end{array}$} & $\begin{array}{l}\text { Surface of the } \\
\text { endothelial } \\
\text { cell }\end{array}$ & $0.00(0.00-0.50)$ & $0.50(0.00-1.50)$ & $1.00(1.00-2.00)$ & $7.006(<0.05)^{\mathrm{B}}$ \\
\hline & $\begin{array}{l}\text { Monocyte/ } \\
\text { Macrophage }\end{array}$ & $0.00(0.00-0.00)$ & $1.00(0.50-1.50)$ & $2.00(1.00-2.00)$ & $12.859(<0.01)^{\mathrm{B}}$ \\
\hline $\begin{array}{l}\text { negative }(0) \text {, weak }(1) \\
\text { H: Kruskal-Wallis val } \\
\text { A: } p<0.05 \text { for control } \\
\text { B: } p<0.05 \text { for control }\end{array}$ & $\begin{array}{l}\text { nild (2), severe (3) } \\
\text { nce analyses } \\
\text { oup and CG group } \\
\text { oup and CG+BK t }\end{array}$ & tment group & & & \\
\hline
\end{tabular}

\section{Discussion}

The healthy peritoneum consists of a monolayer of mesothelial cells attached to a basement membrane. Between the mesothelial layer and the vascular plexus lies the SCZ, which contains fibroblasts, macrophages and blood vessels [4]. EPS is a condition characterized by irreversible fibrosis of the peritoneal membrane and has a high mortality rate [10]. Serial morphological changes in the EPS rats were characterized by marked cellular infiltration and interstitial edema prior to loss of mesothelial cells, prominent neoangiogenesis and eventual severe thickening of interstitial fibrosis [11]. Fibrosis is a normal response to tissue injury and occurs in diverse clinical settings such as wound healing, glomerulonephritis, cirrhosis, and pulmonary fibrosis. In wound healing, fibrosis is a beneficial process that allows wound closure, re-epithelialization, and restoration of normal function. Margetts et al., observed an increase in the SCZ with increased time on peritoneal dialysis [7]. In addition, our study demonstrated that fibrosis was more prominent in the CG+BK treatment group, as indicated by PAS staining.

Macrophages accumulate in the peritoneum and are activated by stimulated resident cells, including 
reactive cubic-shaped mesothelial cells, fibroblasts and infiltrating macrophages at an early stage of EPS. The infiltrating macrophages are able to accelerate peritoneal fibrosis by stimulating fibroblast growth factor production from these peritoneal cells as mentioned in previous reports [11]. It is observed that some inflammation indicators, such as thickening of SCZ, neovascularization, fibrosis and infiltration of PMN's, had highest level in the $\mathrm{CG}+\mathrm{BK}$ treatment group. However, the increase in the count of the flat mesothelial cells was highest in the $\mathrm{CG}$ group, while most reactive cubicshaped mesothelial cells were observed in the $\mathrm{CG}+\mathrm{BK}$ treatment group. On the other hand, monocyte/macrophage infiltration was remarkably aggravated both in $\mathrm{CG}$ and $\mathrm{CG}+\mathrm{BK}$ treatment groups in comparison with the control group. The baseline indicators of the fibrosis included edema and mild infiltration of mononuclear cells in the SCZ. This finding suggested that the peritoneal fibrosis had reached the chronic inflammatory stage. In conclusion, the rate and the extent of the inflammatory response will be determined by the severity of the injury; later, the inflammatory reaction determines the extent of adhesion formation. Considering intra-abdominal surgery, it is an important finding that the operation is, in fact, related with the peritoneal organ.

Mechanisms of peritoneal fibrosis consists of an initiation phase, a progression phase (collagen accumulation), and then either a resolution or a maintenance phase. TGF- $\beta$ plays a central role in fibrosis. It induces MMP-2 and epithelial mesenchymal transition (EMT) of mesothelial cells; it induces secondary cytokines [connective tissue growth factor (CTGF), PAI-1, and tissue inhibitor of metalloproteinase (TIMP)] in fibrosis. The role of inflammation in the maintenance of fibrosis and progression to EPS is not clear [7].
TGF- $\beta 1$, a key mediator of ECM accumulation in fibrotic diseases, has several properties that cause fibrosis. This growth factor is known for its antiinflammatory effects, is chemotactic for fibroblasts and promotes the accumulation of ECM $[6,28]$. TGF- $\beta 1$ overexpression is shown to be responsible for this accumulation through its actions in inducing production of ECM, inhibiting its degradation, and increasing integrin expression, resulting in matrix deposition [29]. TGF- $\beta$ binds to the TGF receptor and activates various intracellular signaling pathways, including the SMAD pathway, is the main signaling system of TGF- $\beta$, which is involved in wound healing and fibrosis [4]. TGF- $\beta 1$ is a multifunctional cytokine involved with many wound healing processes: fibroblast activation, collagen deposition, inhibition of fibrinolysis through PAI-1, maintenance of fibrosis through inhibition of MMP, and angiogenesis [7, 8, 28-30]. Macrophages infiltrating the SCZ express the TGF- $\beta 1$. In the current study, TGF- $\beta 1$ was also expressed by capillary endothelial cells, fibroblasts and monocyte/macrophages. Fibroblasts and monocyte/macrophages were stained more strongly for TGF- $\beta 1$ in the SCZ in the CG and $\mathrm{CG}+\mathrm{BK}$ treatment groups than in control group, and the difference was significant. In fact, the staining was strongest in the $\mathrm{CG}$ group; but, the difference between $\mathrm{CG}$ and $\mathrm{CG}+\mathrm{BK}$ treatment groups was insignificant. On the other hand, we observed stronger staining of superficial endothelial cells in the CG group in comparison with that of the $\mathrm{CG}+\mathrm{BK}$ treatment group; however, there was no statistically significant difference. Peritoneal thickness could not be completely preserved, although the production of TGF- $\beta 1$ was remarkably inhibited. Accordingly, it is clear that several mechanisms other than TGF- $\beta 1$ expression may be responsible for this finding. 
The MMPs and their natural inhibitors are involved in the development and continuation of peritoneal fibrosis. It has been demonstrated that MMPs and tissue inhibitor of matrix metalloproteinases (TIMPs) are produced within the peritoneum by peritoneal mesothelial cells, fibroblasts and macrophages. The increased activity of gelatinases, especially MMP-2, plays a major role in the development of inflammation and fibrosis in EPS models. In peritoneal tissues MMP-2 is present in both the proMMP-2 and active MMP-2 forms [12]. MMP-2 is expressed in endothelial cells that compose microvasculature for angiogenesis and in activated mesothelial cells. In the current study, we determined MMP-2 activities of endothelial cells particularly in the $\mathrm{CG}$ and $\mathrm{CG}+\mathrm{BK}$ treatment groups. MMP-2 is a diagnostic marker for peritoneal injury or EPS [9, 31]. Therefore, MMP-2 may play role in the destruction of peritoneal tissue and reconstitution of basement membrane. Ceri et al. conducted a study using an experimental EPS model and the authors demonstrated that sirolimus significantly reduced peritoneal thickness and fibrosis, but beneficial effect of peritoneal resting could not have been detected. Moreover, they determined the tissue MMP-2 levels that were higher in only CG group than in control group [10]. We observed a weak expression in the control group when the MMP-2 expression level of fibroblasts was examined in the SCZ. Expression was almost completely absent in the CG and $\mathrm{CG}+\mathrm{BK}$ treatment groups. The expression of MMP-2 on the surface of the endothelial cells was greater in the $\mathrm{CG}$ and $\mathrm{CG}+\mathrm{BK}$ treatment groups in comparison with the control group. Monocyte/macrophages did not reveal expression of MMP-2 in the control and CG groups, whereas the expression was significantly greater in $\mathrm{CG}+\mathrm{BK}$ treatment group, although it was weak.Fibrin is often observed clinically in peritoneal injury, peritonitis and EPS. Many studies have suggested that fibrin deposition plays an important role in tissue fibrosis. Fibrin depositions in the tissue matrix is a chemoattractant factor and induces recruitment of inflammatory cells, macrophages and fibroblasts, and leads to the synthesis of the ECM [24]. Fibrin is thought to exude from the blood during reconstruction of vessel walls by production of type IV collagen and MMP2 [9]. In the current study, fibrin deposition was observed in the CG group. The CG group indicated fibrin deposition along the injured mesothelia; but, deposition was not observed in the thickened area of the parietal peritoneum. Peritoneal injury initiates inflammation with fibrinous exudate and fibrin formation. Depending on the severity of the trauma fibrinous exudate is transient due to fibrinolysis, or becomes denser as a result of fibroblasts persisting, leading to fibrinous adhesions. Fibrin results from coagulation cascade activation that is activated in the peritoneal cavity, resulting in the formation of thrombin that triggers conversion of fibrinogen into fibrin. Thus, fibrin forms deposits are a matrix for ingrowth of fibrocollagenous tissue. Indeed, fibroblasts invade the fibrin matrix and the ECM is produced and deposited. This ECM can still be completely degraded by the proenzymes of MMP, leading to normal healing. However, if this process is inhibited by TIMPs, peritoneal adhesions may be formed. Generally, if fibrinolysis does not occur within 5-7 days following the peritoneal injury, the temporary fibrin matrix persists and gradually becomes organized with collagen-secreting fibroblasts. This process leads to peritoneal adhesion formation and growth of new blood vessels mediated by angiogenic factors. Activation of the fibrinolytic system results in the conversion of plasminogen into plasmin that is highly effective in the degradation of fibrin into fibrin degradation products. The cytokines and proteinases, produced 
by invading cells as well as resident cells, also play a part in the regeneration process. A pivotal role is taken by the enzyme plasmin and its promotors and inhibitors; it is mainly the tPA/PAI ratio, which determines the rate of fibrinolysis and therefore the rate of adhesion formation $[1,5,7,8]$.

Plasmin is derived from its inactive substrate plasminogen by tissue type plasminogen activator (tPA) and urokinase-like plasminogen activator (uPA). In its turn, tPA is inhibited in its reaction by PAI-1, to keep the balance. Mesothelial cells produce PAI-1 through TGF- $\beta$ stimulation, has multiple effects as an inhibitor of fibrinolysis and in collagen matrix metabolism. PAI-1 is likely involved at an early stage in peritoneal fibrosis with the inhibition of fibrinolytic activity on the surface of the peritoneal tissue and the subsequent accumulation of fibrin tissue, which forms the initial scaffold for subsequent peritoneal fibrosis. Intra-abdominal surgery disturbs the balance between tPA and PAI-1 resulting in a decreased fibrinolytic activity, an increase in fibrin exudate and eventually an increase in adhesion formation $[5,7,8]$.

PAI activity has been identified in human peritoneal cells. In the inflamed peritoneal tissue the activity of peritoneal plasminogen activators is significantly reduced, partly because the PAI concentration is increased, ultimately leading to a decreased fibrinolytic capacity resulting in adhesion formation [8]. The coagulation and fibrinolysis system also has a significant role in the development of peritoneal fibrosis. Sulaiman et al. observed that tPAdeficient mice were more susceptible to adhesion formation induced by surgical insult and a chronic inflammatory episode [32]. Low levels of tPA and increased levels PAI-1 were recorded in the plasma of chronic peritoneal dialysis patients and experimentally, it has been shown that mesothelial cells produce PAI-1 following
TGF- $\beta$ stimulation [33,34]. In EPS, mesothelial cells are lost from the peritoneal membrane and the fibrinolytic capacity of the peritoneum is reduced, predominantly due to loss of plasminogen activator and increased activity of PAI-1. Over a prolonged period, or following repeated insults, the reduced fibrinolytic capacity may contribute to peritoneal fibrosis [35]. In the current study, the fibrin deposition was observed in the $\mathrm{CG}$ group, while it disappeared in the $\mathrm{CG}+\mathrm{BK}$ treatment group. Surface of the endothelial cells were more strongly stained with for PAI-1 in the CG and $\mathrm{CG}+\mathrm{BK}$ treatment groups in comparison with that of the control group.

Nishimura et al., demonstrated that overexpression of TGF- $\beta 1$ and PAI-1, which peaked at day 7 and was associated with histological changes consistent with peritoneal fibrosis and neoangiogenesis, was suppressed by spironolactone. In particular, the elevation of PAI-1 in their model was marked. Aldosterone blockade was shown to prevent renal injury by suppressing inflammation and antifibrotic effects, such as TGF- $\beta 1$, PAI- 1 , and connective tissue growth factor. TGF- $\beta 1$ and PAI-1, plays a role in the progression of peritoneal fibrosis in the scraping model and that spironolactone effectively suppresses this cytokine network, leading to prevention of peritoneal fibrosis and dysfunction [36].

The roles of PAI-1, MMP-2 and TGF- $\beta$ on induction of fibrosis have been shown in rat models of EPS [37, 38]. In the current study, the expression of TGF- $\beta 1$, MMP-2 and PAI-1 increased in the SCZ in the CG group due to the increased fibrosis and inflammation; same findings were also observed in the previous studies, except weak MMP-2 and PAI-1 staining in fibroblasts in comparison with the stronger staining in the control group.

The BK, a potent short-lived peptide, is that participates in inflammation and 
vascular regulation, including processes such as angioedema, tissue permeability, vascular dilatation, and smooth muscle contraction. Within the peritoneal cavity $\mathrm{BK}$ is known to increase the peritoneal dialysis clearance and has been implicated in the mediation of peritoneal inflammation and increased peritoneal permeability [39]. BK-induced proinflammatory mechanisms involve leukocyte-endothelial cell adhesive interactions in postcapillary venules. BK exerts its effects after stimulation of cell surface receptors. BK receptors, B1 (B1R) and B2 (B2R), have been defined based on their pharmacological properties [16]. The B2R is constitutively expressed at the vascular level, and it is also expressed on neutrophils [12]. B2R appears to be the principal kinin receptor under physiological conditions and at the acute stage of the inflammatory response. B2R has a short, but strong response to the stimulation; it immediately undergoes rapid desensitization of functional responses. In a study, Sainz et al. showed that by inhibiting the activation of B1R, the inflammatory response increases and persists when compared with the natural evolution of the disease in their animal model. In contrast, by blocking B2R there is no significant effect. When both $\mathrm{B} 1 \mathrm{R}$ and $\mathrm{B} 2 \mathrm{R}$ are blocked, the increase of inflammation as observed in the B1R antagonist treatment is neutralized, and there is no difference from the diseaseuntreated model [2].

There is only little information about the role of $\mathrm{BK}$ in the damaged peritoneum during dialysis. It has been previously reported that BK level is increased in the peritoneal exudates induced by carrageenin in rats [40]. In vitro studies informed us that BK performed its effects on peritoneum mainly via $\mathrm{BK}-\mathrm{B} 2$ receptor [39, 41-43]. However, BK-B2 receptors and their relation with peritoneal fibrosis had never been shown in the EPS model. Our aim was to distinguish the effects of
BK-B2 receptor stimulation from the local proinflammatory effects of BK which was systemically infused. The BK-B2 receptor expression of the control group was mild in the flat mesothelial cells; no staining was observed in $\mathrm{CG}$ and $\mathrm{CG}+\mathrm{BK}$ treatment groups. However, fibroblast BK-B2 receptor expression was stronger in the SCZ of the $\mathrm{CG}$ and $\mathrm{CG}+\mathrm{BK}$ treatment groups in comparison with that of the control group, resulting with no statistically significant difference. The control group demonstrated no staining on superficial endothelial cells and monocytes/macrophages. Expression increased in the $\mathrm{CG}$ and $\mathrm{CG}+\mathrm{BK}$ treatment groups. Statistically significant difference was observed between the control group and the $\mathrm{CG}+\mathrm{BK}$ treatment group.

Recent studies have indicated that stimulation of BK-B2 receptors may attenuate fibrosis in renal and liver injury. It has been postulated in these studies that BK exerts this antifibrotic effect via decreasing PAI-1 expression, and in turn decreasing the levels of MMP-2 and TGF$\beta$ which are the main mediators of fibrosis. The information about the effects of $\mathrm{BK}$ on peritoneum is mainly focused on the acute inflammation but not on the long term results, such as fibrosis [16-19]. In the current study, staining of monocyte/macrophages was stronger in the $\mathrm{CG}+\mathrm{BK}$ treatment group in comparison with the $\mathrm{CG}$ group. In the light of this finding, we believe that the BK-stimulated B2 receptors may activate peritoneal macrophages.

In the light of previous studies, we also aimed to observe the effects of $\mathrm{BK}$ on PAI-1 expression in order to examine any possible antifibrotic activity of BK. The current study shows that BK-B2 receptors are expressed locally in normal rat peritoneum and they are remarkably upregulated in the rat peritoneum by induction of EPS. Moreover, we provide 
evidence that BK infusion exerts inflammatory effects and increases peritoneal fibrosis. On the other hand, we observed that the stimulation of BK-B2 receptors by systemic infusion of $\mathrm{BK}$ did not have any antifibrotic effects on the rat EPS models; but it may actually increase fibrosis and the mechanism most probably involves the proinflammatory pathways. We have shown that BK-B2 receptor activation aggravated the BK-induced peritoneal fibrosis. Peritoneal fibrosis was more severe in $\mathrm{CG}+\mathrm{BK}$ treatment group in comparison with that of the CG group. PAI-1 activity significantly decreased in the $\mathrm{CG}$ and $\mathrm{CG}+\mathrm{BK}$ treatment groups. The way the BK modifies the activity and release of PAI-1 is not known. Plasmin can transform MMPs from the latent form to the active form. We suggested that the disactivation of PAI-1 and MMP-2 in the fibroblasts of the $\mathrm{CG}$ and $\mathrm{CG}+\mathrm{BK}$ treatment groups may be related with the increased peritoneal fibrosis. This finding is indicating that $\mathrm{BK}-\mathrm{B} 2$ receptor activity/PAI-1 activity/MMP-2 activity cascade may play a role in the degradation of ECM. This study emphasizes the importance of BK-B2 receptors in the development of EPS and thus, it may provide a new insight to the current therapeutic strategies.

\section{Conclusions}

Postoperative peritoneal adhesion is a major health problem, resulting with a significant economic impact. Several studies had investigated this problem. The results of those studies are encouraging, but most of them are contradictory and have been conducted in animal models. Recent studies have revealed out many new aspects of peritoneal cell biology and immunology with respect to the fibrosis and inflammation. Further advances in immunology and molecular biology will certainly with opportunities to develop new strategies in order to prevent EPS, and preclinical or clinical studies are still necessary to evaluate the effectiveness of the several proposed prevention strategies for postoperative peritoneal adhesions.

\section{REFERENCES}

1. Arung, W. Meurisse, M. Detry, O. (2011). Pathophysiology and prevention of postoperative peritoneal adhesions. World J Gastroenterol, 17(41), 4545-4553.

2. Bozkurt, D. Taskin, H. Sezak, M. Bıçak, S. Sen, S. Ok, E. et al. (2008). Rosiglitazone, a peroxisome proliferator-activated receptor agonist, improves peritoneal alterations resulting from an encapsulated peritoneal sclerosis model. Adv Perit Dial. 24, 32-38.

3. Braun, N. Alscher, M.D. Kimmel, M. Amann, K. Büttner, M. (2011). Encapsulating peritoneal sclerosis-an overview. Nephrol Ther.7, 162-171.

4. Korte, M.R. Sampimon, D.E. Betjes, M.G.H. Krediet, R.T. (2011). Encapsulating peritoneal sclerosis:
The state of affairs. Nat Rev Nephrol, 7, 528-538.

5. Miyazaki, M. Yuzawa, Y. (2005). The role of peritoneal fibrosis in encapsulating peritoneal sclerosis. Perit Dial Int. 25(4),48-56.

6. Sawada, T. Ishii, Y. Tojimbara, T. Nakajima, I. Fuchinoue, S. Teraoka, S. (2002). The ace inhibitor, quinapril, ameliorates peritoneal fibrosis in an encapsulating peritoneal sclerosis model in mice. Pharmacol Res. 46(6), 505-510.

7. Margetts, P.J. Bonniaud, P. (2003). Basic mechanisms and clinical implications of peritoneal fibrosis. Perit Dial Int. 23,530-541.

8. Wal, J.B.C. Jeekel, J. (2007). Biology of the peritoneum in normal 
homeostasis and after surgical trauma. Colorectal Dis. 9(Suppl.2), 9-13.

9. Hirahara, I. Kusano, E. Yanagiba, S. Miyata, Y. Ando, Y. Muto, S. et al. (2006). Peritoneal injury by methylglyoxal in peritoneal dialysis. Perit Dial Int. 26, 380-92.

10. Ceri, M. Unverdi, S. Dogan, M. Unverdi, H. Karaca, G. Kocak, G. et al. (2012). Effect of sirolimus on the regression of peritoneal sclerosis in an experimental rat model. Int Urol Nephrol. 44, 977-982.

11. Ro, Y. Hamada, C. Inaba, M. Io, H. Kaneko, K. Tomino, Y. (2007). Inhibitory effects of matrix metalloproteinase inhibitor ONO-4817 on morphological alterations in chlorhexidine gluconate-induced peritoneal sclerosis rats. Nephrol Dial Transplant. 22(10), 2838-2848.

12. Uçar, E. Borazan, A. Semerci, E. Binici, D.N. Yaldı, M. Aysal, A. et al. (2010). The effect of interferon $\alpha 2 b$ on chemically-induced peritoneal fibrosis and on peritoneal tissue MMP2 and TIMP-2 levels in rats. $J$ Int Med Res. 38, 187-194.

13. Griesbacher, T. Lembeck, F. (1987). Effect of bradykinin antagonists on bradykinin-induced plasma extravasation, venoconstriction, prostaglandin E2 release, nociceptor stimulation and contraction of the iris sphincter muscle in the rabbit. $\quad B r J$ Pharmacol. 92(2), 333-340.

14. Juan, H. Lembeck, F. (1974). Action of peptides and other algesic agents on paravascular pain receptors of the isolated perfused rabbit ear. Naunyn Schmiedebergs Arch Pharmacol. 283(2), 151-64.

15. Leeb-Lundberg, L.M. Marceau, F. Müller-Esterl, W. Pettibone, D.J. Zuraw, B.L. (2005). International union of pharmacology. XLV. Classification of the kinin receptor family: from molecular mechanisms to pathophysiological consequences. Pharmacol Rev. 57(1), 27-77.
16. Schanstra, J.P. Neau, E. Drogoz, P. Arevalo Gomez, M.A. Lopez Novoa, J.M. Calise, D. et al. (2002). In vivo bradykinin B2 receptor activation reduces renal fibrosis. J Clin Invest. 110(3), 371-379.

17. Okada, H. Watanabe, Y. Kikuta, T. Kobayashi, T. Kanno, Y. Sugaya, T. et al. (2004). Bradykinin decreases plasminogen activator inhibitor-1 expression and facilitates matrix degradation in the renal tubulointerstitium under angiotensinconverting enzyme blockade. $J A m$ Soc Nephrol. 15(9), 2404-2413.

18. Sancho-Bru, P. Bataller, R. Fernandez-Varo, G. Moreno, M. Ramalho, L.N. Colmenero, J. et al. (2007). Bradykinin attenuates hepatocellular damage and fibrosis in rats with chronic liver injury. Gastroenterol. 133(6), 2019-2028.

19. Zhang, J.J. Bledsoe, G. Kato, K. Chao, L. Chao, J. (2004). Tissue kallikrein attenuates salt-induced renal fibrosis by inhibition of oxidative stress. Kidney Int. 66(2), 722-732.

20. Sainz, I.M. Uknis, A.B. Salas, II. Cadena, R.A. Pixley, R.A. Colman, R.W. (2004). Interactions between bradykinin (BK) and cell adhesion molecule (CAM) expression in peptidoglycan-polysaccharide (PGPS)-induced arthritis. FASEB J. 18, 887-889.

21. Mishima, Y. Miyazaki, M. Abe, K. Ozono, Y. Shioshita, K. Xia, Z. et al. (2003). Enhanced expression of heat shock protein 47 in rat model of peritoneal fibrosis. Perit Dial Int. 23(1), 14-22.

22. Günal, A.I. Celiker, H. Akpolat, N. Üstündag, B. Duman, S. Akcicek, F. (2002). By reducing production of vascular endothelial growth factor octreotide improves the peritoneal vascular alterations induced by hypertonic peritoneal dialysis solution. Perit Dial Int. 22, 301-306. 
23. Ignjatovic, D. Aaslandb, K. Pettersena, M. Sundc, S. Chend, Y. Spasojevice, M. et al. (2010). Intra-abdominal administration of bevacizumab diminishes intra-peritoneal adhesions. Am J Surg. 200, 270-5.

24. Ishii, Y. Sawada, T. Shimizu, A. Tojimbara, T. Nakajima, I. Fuchinoue, S. et al. (2001). An experimental sclerosing encapsulating peritonitis model in mice. Nephrol Dial Transplant. 16, 1262-1266.

25. Mun, K.C. Yeo, M.Y. Kim, S.P. Kim, H.C. Kwak, C.S. (2000). Chronic peritoneal inflammation by cyanate in rats. Perit Dial Int. 20, 699-702.

26. Vrtovsnik, F. Coester, A.M. LopesBarreto, D. Waart, D.R. Wal, A.C.V. Struijk, D.G. et al. (2010). Induction of chronic kidney failure in a longterm peritoneal exposure model in the rat: effects on functional and structural peritoneal alterations. Perit Dial Int. 30, 558-569.

27. Sobel, B.E. Mitchell, J.W. Schneider, D.J. Holt, R.E. Marutsuka, K. Gold, H. (1998). Increased plasminogen activator inhibitor type 1 in coronary artery atherectomy specimens from type 2 diabetic compared with nondiabetic patients. A potential factor predisposing to thrombosis and its persistence. Circulation. 97, 2213-21.

28. Decologne, N. Kolb, M. Margetts, P.J. Menetrier, F. Artur, Y. Garrido, C. et al. (2007).TGF- $\beta 1$ induces progressive pleural scarring and subpleural fibrosis. J Immunol. 179, 6043-6051.

29. Duman, S. Günal, A.I. Sen, S. Asçi, G. Özkahya, M. Terzioglu, E. et al. (2001). Does enalapril prevent peritoneal fibrosis induced by hypertonic $(3.86 \%)$ peritoneal dialysis solution? Perit Dial Int. 21, 219-224.

30. Guo, H. Leung, J.C.K. Lam, M.F. Chan, L.Y.Y. Tsang, A.W.L. Lan, H.Y. et al. (2007). Smad7 transgene attenuates peritoneal fibrosis in uremic rats treated with peritoneal dialysis. $J$ Am Soc Nephrol. 18, 2689-2703.
31. Hirahara, I. Ogawa, Y. Kusano, E. Asano, Y. (2004). Activation of matrix metalloproteinase-2 causes peritoneal injury during peritoneal dialysis in rats. Nephrol Dial Transplant. 19(7), 1732-1741.

32. Sulaiman, H. Dawson, L. Laurent, G.J. Bellingan, G.J. Herrick, S.E. (2002). Role of plasminogen activators in peritoneal adhesion formation. Biochem Soc Trans. 30(2), 126-131.

33. Opatrny, K. Opatrna, S. Vit, L. Opatrny, K. (1998). Tissue-type plasminogen activator (tPA) and its inhibitor (PAI-1) in patients treated with continuous ambulatory peritoneal dialysis. Am J Nephrol. 18(3), 186192.

34. Rougier, J.P. Guia, S. Hagege, J. Nguyen, G. Ronco, P.M. (1998). PAI-1 secretion and matrix deposition in human peritoneal mesothelial cell cultures: transcriptional regulation by TGF-beta 1. Kidney Int. 54(1), 87-98.

35. Pollock, C.A. (2001). Diagnosis and management of encapsulating peritoneal sclerosis. Perit Dial Int. 21(Suppl3), 61-66.

36. Nishimura, H. Ito, Y. Mizuno, $M$. Tanaka, A. Morita, Y. Maruyama, S. et al. (2008). Mineralocorticoid receptor blockade ameliorates peritoneal fibrosis in new rat peritonitis model. Am J Physiol Renal Physiol. 294, 1084-1093.

37. Mondello, S. Mazzon, E. Di Paola, R. Crisafulli, C. Italiano, D. Buerni, M. et al. (2009). Erythropoietin suppresses peritoneal fibrosis in rat experimental model. Eur J Pharmacol. 604(1-3), 138-149.

38. Williams, R.S. Rossi, A.M. Chegini, N. Schultz, G. (1992). Effect of transforming growth factor beta on postoperative adhesion formation and intact peritoneum. J Surg Res. 52(1), 65-70.

39. Andre, M. Rahimi, S. Schollmeyer, P. Pavenstadt, H. (1998). Bradykinin stimulates intracellular calcium 
activity in human mesothelial cells. Nephrol Dial Transplant. 13, 2047-2052.

40. Damas, J. Bourdon, V. RemacleVolon, G. Adam, A. (1990). Kinins and peritoneal exudates induced by carrageenin and zymosan in rats. $\mathrm{Br} J$ Pharmacol. 101(2), 418-422.

41. Böckmann, S. Mohrdieck, K. Paegelow, I. (1999). Influence of interleukin-1 beta on bradykinininduced responses in guinea pig peritoneal macrophages. Inflamm Res, 48(1), 56-62.

42. Böckmann, S. Mohrdieck, K. Schmidt H, Zündorf G, Paegelow I: Differential sensitivity of macrophages to bradykinin. Naunyn Schmiedebergs Arch Pharmacol 1998,357(2), 151158.

43. Böckmann, S. Paegelow, I. (1995). Bradykinin receptors in signal transduction pathways in peritoneal guinea pigs macrophages. Eur $J$ Pharmacol. 291(2),159-65. 